\title{
Response to commentary by Howard Waitzkin*
}

June 24, 2020

We appreciate this opportunity to respond to Dr. Waitzkin's commentary. But first, we want to provide some background on the origins of our article. We first met in Santiago in 2016, when Carter, a historical geographer with many publications on the history of public health, was in the early stages of a book project on the origins of Latin American social medicine. Meanwhile, Sánchez Delgado, a historian of science, has just completed his dissertation on early twentieth-century eugenics in Chile and Argentina, and was in the midst of a three-year project, funded by Chile's Fondecyt, to analyze the actors and networks involved in the development of anatomical pathology as a discipline in Chile from the late nineteenth century to 1950 .

When Carter began developing his research project, Waitkzin's publications on Latin American social medicine, in English and Spanish, were an important touchstone. Naturally, retracing some of Waitzkin's own sources, and engaging his arguments and interpretations, were a key part of the research process. At our first meeting, we (Carter and Sánchez Delgado) realized that we had both arrived, independently, at a skeptical view of Waitzkin's narrative of the origins of social medicine in Chile in the early 1900s, which depended on personal connections and a shared philosophy between Virchow, Westenhöfer, and Allende. And, as time went on, we became increasingly troubled that this origin story had become widely diffused, exaggerated and simplified in the retelling, seriously distorting a complex and rich history of Chilean science and politics. We came to feel that rectifying this relatively minor point of fact could have important consequences, not just for our understanding of this history, but for historiographical practice, especially for research oriented towards the analysis of scientific expert networks between Europe and Latin America in the early twentieth century.

Unfortunately, rather than engaging our arguments, Dr. Waitzkin uses most of his commentary to launch unjustifiable attacks on the character of one of us (Carter). What is most troubling is that Dr. Waitzkin calls Carter's professional and intellectual integrity into question. We emphasize that Dr. Waitzkin read a draft version of our paper and commented on it before it was accepted for publication. We were under no obligation to offer him this opportunity, as scholarly researchers are not required by any code of ethics

* [Editor's note] This letter replies another letter published (http://dx.doi.org/10.1590/S010459702020000400019) in this issue. 
to seek prior approval of their work from scholars they might disagree with. We chose to share the draft with Dr. Waitzkin as a courtesy, out of respect for his important role in the promotion of social medicine in the United States and Latin America, and, most importantly, to make sure that we had gotten our facts straight. Dr. Waitzkin's response to the draft version of this article, which we received back in January 2019, did not present any new and compelling evidence that would lead us to change our analysis substantially, but we did make some minor edits based on his feedback.

The peer review procedure of História, Ciências, Saúde - Manguinhos is beyond our control as authors. However, from our vantage point, the journal followed the accepted norms for peer review of scholarly work, by inviting three different reviewers in a double-blind format, which is meant to encourage honesty in evaluation. The decision not to invite Dr. Waitzkin to serve as a peer reviewer was made by Marcos Cueto, the editor, not by the authors. But it is clear from his commentary that Dr. Waitzkin lacks the objectivity and fairmindedness that are expected of a peer reviewer, at least on this particular topic.

In addition, Dr. Waitzkin has been granted the opportunity to respond to our work in a published commentary, something that is rarely done in academic journals. As a result, his commentary, despite its groundless accusations, will be linked to our original research article in perpetuity, and readers can draw their own conclusions about who makes the more convincing argument. Other researchers might even follow up with new evidence and interpretations that would clarify some of our points of disagreement.

Turning to the substance of Dr. Waitzkin's critique, we are confused by his stance on one of the key claims we make in our article, namely that Salvador Allende was not a student of Max Westenhöfer's in Chile. On the one hand, he seeks to distance himself from a claim that he had made previously, in several works, which implied (at the very least) that this teacher-student relationship had existed. We quote Waitzkin (2006, p.8) again here (in the original Spanish, so none of the meaning is lost):

Max Westenhofer, un importante patólogo alemán influenciado por Virchow, dirigió por muchos años el departamento de patología en la escuela de medicina de la Universidad de Chile e influyó sobre generaciones de estudiantes, incluyendo a Salvador Allende, estudiante de medicina y activista y futuro presidente de Chile.

We agree that it is a good idea to rethink this claim, since there is really no good evidence to support it, as we explain in great depth in the article. Yet, at the same time, Dr. Waitzkin still seeks evidence to support his claim, alluding to an interview with he did with Maria Angélica Illanes, the Chilean historian, sometime between 1994 and 1996, as the original source for his assertion. However, Illanes never made this claim in writing, in her valuable book En el nombre del pueblo, del Estado y de la ciencia, neither in the 1993 original edition nor the 2010 updated edition.

Dr. Waitzkin presents weak evidence to support his claim for Westenhöfer's influence on social medicine in Chile. In his commentary, Dr. Waitzkin alludes to "a trusted informant" who "reconfirmed his earlier statements about Westenhöfer's long-term influence on Allende's generation and even the subsequent generation of people working in Chilean social medicine." This kind of statement - which basically amounts to "someone I trust 
told me that it's true" - is not evidence in the conventional sense, as something that other researchers might be able to verify and question for themselves. In addition, the claim of Westenhöfer's influence on Chilean social medicine is highly doubtful in its substance, since no one other than Waitzkin, or those who cite Waitzkin as a source, have made this claim in print. As to our failure to cite Westenhöfer's work in German, it is important to note that one of us (Sánchez Delgado) has become the preeminent expert in Chile on Westenhöfer's work, and has closely studied the networks that linked German and Chilean academic circles in anatomical pathology. He has consulted documents in Spanish and German written by Westenhöfer, in archives in Germany, for his dissertation and other published articles. By way of a thorough analysis of the whole corpus of Westenhöfer's work, Sánchez Delgado concluded, as we state in the article, that Westenhöfer advanced the cause of scientific racism with his studies in anatomical pathology and biological anthropology, and contributed little to what most of us would consider to be social medicine.

We can concede the point that Westenhöfer's study of 1911 on mortality and morbidity in Chile, "Informe sobre la actividad del Instituto de Anatomía Patológica de la Universidad de Chile en los años 1908-09," does bear some "resemblance in analytic techniques and interpretations" to Virchow's research, as Waitzkin states in his commentary. We agree that it is interesting that Westenhöfer would use his skills in anatomy and pathology, which he unquestionably developed under the mentorship of Rudolf Virchow, as the foundation for a more general analysis of population health, at a time when vital records for epidemiological analysis were scarce in Chile. Still, we continue to argue that Westenhöfer had limited influence on Chilean scientists and officials in public health and social medicine. The figures of the Vanguardia Médica, which included Allende, or others involved in public health from 1920s to the 1940s, never cited the work of Westenhöfer, in part because his 1911 study was not translated into Spanish until 1958 (after Westenhöfer's death), but also because they increasingly produced their own research studies on the alarming health, nutrition, and social conditions of Chile during that period, in the mode of a hygiene movement that was widespread in Latin America at the time. During that lapse of four decades, Chilean public health science and policy developed rapidly under a wide range of local and international influences, as we explain in the article. If Westenhöfer had any role in that process, it would be minimal.

We also want to restate a point we make quite clearly in the article: the tale of the social medicine lineage between Virchow, Westenhöfer, and Allende has now taken on a life of its own, so that Dr. Waitzkin's originally narrow claim has turned into the "fact" that Virchow's social medicine philosophy was passed down through Westenhöfer to Allende. We have explained how the scope and significance of the claim grows with each retelling, for example in Adam Gaffney's book on health and human rights, which we cite. That is why we take care to state that we are interrogating the veracity of the narrative (el relato), not the integrity of Dr. Waitzkin himself. Indeed, we do not even mention or cite Dr. Waitzkin in the introduction to the article, which sets the stage for our argument, since there are so many other sources that illustrate the blind acceptance and exaggeration of this dubious story. 
In conclusion, our article and this exchange of perspectives highlight the multiple and complex roles of historians in telling stories about our past. As Roy Porter and Dorothy Porter, among others, have explained, European-American historians of the mid-twentieth century (such as Sigerist, Rosen, and Ackerknecht) were critical actors in resurrecting historical figures (such as Virchow) to demonstrate the deep intellectual and political roots of the social medicine idea. In this way, historians have the power to conjure up the past, to give meaning and value to the projects and ambitions of the present. When Dr. Waitzkin and his colleagues began to write up the history of Latin American social medicine a few decades ago, they performed a valuable service in bringing the past to life and presenting alternative visions for more just and equitable health policies in Latin America and elsewhere. Just as Sigerist, Rosen, and Ackerknecht had done a generation before, Howard Waitzkin, Gustavo Molina, and Juan César García, among others, offered a historical account that courageously defied reactionary viewpoints and authoritarian repression.

But historical researchers also have the obligation to seek the truth, basing claims on firm evidence and sound methods. Thus we have not just the right, but the obligation, to disagree with others. While Dr. Waitzkin attacks our reputation as scholars, we instead view reasonable disagreement as the essence of intellectual integrity. Again, we leave it to readers to judge the rightness of our actions and the persuasiveness of our arguments.

\section{REFERENCE}

WAITZKIN, Howard.

Un siglo y medio de olvidos y redescubrimientos: las perdurables contribuciones de Virchow a la medicina social. Medicina Social, v.1, n.1, p.5-10. 2006.

Eric D. Carter

'Professor, Geography Department/Macalester College.

Saint Paul - MN - USA

orcid.org/0000-0002-6766-1626

ecarter@macalester.edu

Marcelo Sánchez Delgado

ii Professor, Historical Sciences Department/Universidad de Chile. Santiago de Chile - Chile orcid.org/0000-0002-7697-3699 historia.mjsd@gmail.com

Recebido em 24 jun. 2020. Aprovado em 28 jun. 2020. 